\title{
下顎骨区域切除後にチタンプレートにて下顎再建した 高齢者の術後機能に関する検討
}

\author{
山下佳 雄 後藤昌 昭
}

\begin{abstract}
要 旨
下顎歯肉癌や顎骨中心性癌のため下顎骨区域切除を行った患者に対して，硬性再建として一時的に再建プレート にて下顎骨を固定し, 術後に腫瘍の再発や転移がない場合に解剖学的形態に下碩を再建することがある。しかし 80 歳以上の高齢者では，全身状態や家族の希望を考慮してプレートによる下顎再建で治療を終えることが多い。

今回, 2008 年から 2010 年までの 3 年間に 80 歳以上で口腔癌のため下䫟骨区域切除術を施行し, 再建プレート にて下顎骨を再建した患者 7 名 (男性 2 名, 女性 5 名; 平均年齢 82.3 歳) を対象として, 術後の合併症, 摂食機能, 審美的，機能的満足度に関して検討した。

術後, 経口摂取開始までの日数は平均 15.6 日であった。術後の合併症としては局所感染が 1 例，プレート破折 が 1 例認められた。術後の Helkimo index のスコアーは平均 0.86 点と低く, 顎運動の障害は少なかった。山本の 咬度表による術後の摂食機能評価も平均 4.4 点と満足のいくものであった。また術後の会話機能には問題なかった が，審美的満足度については女性は低い結果であった。

長時間の手術や他部位への手術侵襲は 80 歳以上の高齢者には負担が大きい。再建プレートによる下顎骨再建は 術後の顔貌形態や咀嚼機能にやや問題はあるものの, 術後合併症も少なく早期の離床が可能で，高齢者の QOL 向 上に貢献し得ると考える。
\end{abstract}

キーワード：下顎再建，再建プレート，高齢者，術後合併症，咀嚼機能

Postoperative function in elderly patients with mandibular reconstruction using a titanium plate following segmental mandibulectomy:

Yoshio Yamashita and Masaaki Goto

Department of Oral and Maxillofacial Surgery, Saga Medical School

\section{Summary}

For some patients who have undergone segmental mandibulectomy for lower gingival carcinoma or intraosseous carcinoma of the mandible, rigid reconstruction is performed by temporarily fixing the mandible using a reconstruction plate, followed by morphological and functional mandibular reconstruction in cases with no postoperative tumor recurrence or metastasis. However, in patients $\geq 80$ years old, treatment is often concluded with mandibular reconstruction using a plate in consideration of the patient's general status and the family's wishes.

The present study investigated postoperative complications, eating function, and esthetic and functional satisfaction in 7 patients ( 2 men, 5 women; mean age, 82.3 years) who underwent segmental mandibulectomy for oral cancer at $\geq 80$ years old, followed by mandibular reconstruction using a reconstruction plate between 2008 and 2010 .

Following surgery, mean time to initiation of ingestion was 15.6 days. Postoperative complications comprised 1 case of local infection and 1 case of plate fracture. Mean postoperative Helkimo Index score was low, at 0.86 points, and few patients showed impaired jaw movement. Mean postoperative score for Yamamoto's occlusion table was 4.4, indicating satisfactory eating function. In addition, although no problems were encountered for postoperative speech, women showed a low level of satisfaction with esthetic outcome.

Prolonged surgery and surgical invasion into other sites exert a heavy burden on individuals $\geq 80$ years old. Although mandibular reconstruction using a reconstruction plate may result in some problems in terms of postoperative facial appearance and masticatory function, few postoperative complications arise and early ambula-

佐賀大学医学部歯科口腔外科学講座

[平成 23 年 8 月 26 日受付, 平成 23 年 11 月 25 日受理］
別刷請求先 : $=849-8501$ 佐賀県佐賀市鍋島 5-1-1 佐賀大学医学部歯科口胿外科学講座 山下 佳雄 
tion is enabled. This approach may thus contribute to enhanced quality of life in the elderly.

Key words : Mandibular reconstruction, Reconstruction plate, Elderly patients, Postoperative complications, Masticatory function

[Received Aug. 26, 2011, Accepted Nov. 25, 2011]

\section{はじめに}

頭頸部癌の術後に生じた実質欠損に対しては，審美性及 び咀嚼, 嚥下といった機能性の両面に十分な配虑した再建 術を行わなくてはならない。近年, マイクロサージャリー の技術進歩により満足のいく結果を得ることが可能となっ た。しかしながら高齢者においては既往，合併症を含め全 身状態を念頭において出来る限り低侵襲の手術法を選択 しなくてはならない。今回, 80 歳以上の高齢者に対して, 下顎再建のため再建プレートを使用することが妥当か, 術 後の合併症を含め術後の咀嚼機能，ならびに患者の満足度 に関して検討した。

\section{対象と方法}

対象は佐賀大学医学部附属病院歯科口腔外科にて 2008 年 4 月から 2011 年 3 月までの 3 年間に口腔癌のため下顎 骨区域切除術を施行し, 再建プレートにて下顎骨を再建し た 80 歳以上の患者 7 名である。男性 2 名, 女性 5 名で平 均年齢は 82.3 歳だった。病理組織診断は骨肉腫の 1 名を 除き全例扁平上皮癌であった（表 1 )。

治療体系としては 1 例のみ術前治療として化学放射線療 法を施行したが，その他は外科手術のみを行った。

再建プレートは全症例，Mondeal 社製（ドイツ）の BULL Mandibular Reconstruction System を使用し, 切除端に 少なくとも 3 本以上のスクリューを用いて bicortical に固 定を行った。今回の対象症例には，切除範囲が舌にまで及 び舌実質の欠損が生じた症例はなかった。軟組織の処理に 関しては 4 例が縫縮のみであったが，欠損の大きかった 3 症例については有茎皮弁（大胸筋皮弁, 頸部島状皮弁）な らびに局所皮弁（鼻唇溝皮弁）を用い再建した。
創部の安静を保つため, 全症例で顎間固定を施行した。固 定期間は平均 15.6 日（11～20日）であり，固定解除後よ

り経口摂取を開始した（表 2$)$ 。

検討項目

下記の $6 つ の$ 項目に関して検討を行った。

1. 術後の合併症

術後の局所感染, 縫合不全, 瘦孔形成, 皮弁壊死, 開口 障害ならびにプレートの破折などの有無に関して検討し た。

\section{2. 会話機能評価}

術後の会話機能評価として「広瀬の会話分類機能」に基 づいて評価を行った。評価時期としては術後 6 ケ月とし た。

3. 臨床的顎関節機能検査

顎関節機能障害の程度を評価する Helkimoの審査方法 をもとに栗田ら ${ }^{1)}$ が考案した顎関節機能検査に準じて調査 した。術後 6 ヶ月時の顎運動の障害, 顎関節の機能障害, 顎運動時の疼痛, 顎関節部圧痛, 筋肉部圧痛の 5 項目につ いて診察し，障害度点数（各 $0 \sim 5$ 点）を加算して定量化 した。

4. 食物摂取調査

「山本の咬度表」に基づいて, 術後 6 ケ月時にアンケー 卜調査を行った。患者が摂取可能と解答した食品が半数以 上を占める最高の咬度を患者の評点とした。

5. 咬合接触面積と咬合力測定

術後 6 ケ月時の咬合接触面積と咬合力を計測した。義歯 を使用している場合は，義歯を装着した状態で計測を行っ た。

測定にはデンタルプレスケール（富士写真フィルム株式 会社，東京）を使用した ${ }^{2)}$ 。患者を座位とし，咬合平面が

表 1 症例一覧

\begin{tabular}{|c|c|c|c|c|c|c|c|}
\hline 症例 & 年齢 & 性別 & 部位 & 左右 & TNM 分類 & 病理組織型 & 治療体系 \\
\hline 1. & 80 歳 & 女性 & 下顎骨 & 右側 & T4N0M0 & osteosarcoma & $\mathrm{O}$ \\
\hline 2. & 80 歳 & 男性 & 下顎歯肉 & 左側 & T4N0M0 & $\mathrm{SCCw}$ & $\mathrm{RC}-\mathrm{O}$ \\
\hline 3. & 81 歳 & 女性 & $\begin{array}{l}\text { 下顎歯肉 } \\
\text { (上顎歯肉 }\end{array}$ & $\begin{array}{l}\text { 右側 } \\
\text { 右側) }\end{array}$ & T4N2bM0 & $\mathrm{SCCw}$ & $\mathrm{O}$ \\
\hline 4. & 86 歳 & 女性 & 下顎歯肉 & 正中 & T4N0M0 & SCCw & $\mathrm{O}$ \\
\hline 5. & 83 歳 & 女性 & 顎骨中心性 & 左側 & T4N0M0 & $\mathrm{SCCw}$ & $\mathrm{O}$ \\
\hline 6. & 80 歳 & 男性 & 顎骨中心性 & 左側 & T4N2bM0 & $\mathrm{SCCm}$ & $\mathrm{O}$ \\
\hline 7. & 86 歳 & 女性 & 顎骨中心性 & 左側 & T4N0M0 & $\mathrm{SCCw}$ & $\mathrm{O}$ \\
\hline
\end{tabular}


表 2 症例別の手術内容・転帰

\begin{tabular}{clccc}
\hline \hline 症例 & \multicolumn{1}{c}{ 頸部郭清 } & 皮弁再建 & 顎間固定期間 (日) & 転帰 \\
\hline 1. & 顎下部郭清 & cervical island flap & 19 & 担癌生存 \\
2. & 肩甲舌骨筋上頸部郭清 & PMMC & 17 & 生存 \\
3. & 肩甲舌骨筋上頸部郭清 & $(-)$ & 14 & 生存 \\
4. & 肩甲舌骨筋上頸部郭清 + 顎下部郭清 & nasolabial flap & 11 & 生存 \\
5. & 肩甲舌骨筋上頸部郭清 & $(-)$ & 20 & 原発死 \\
6. & 根治的頸部郭清 & $(-)$ & 15 & 生存 \\
7. & 顎下部郭清 & $(-)$ & 13 & 生存 \\
\hline
\end{tabular}

(平均：15.6 日)

表 3 術後の咬合状態

\begin{tabular}{|c|c|c|c|c|c|c|}
\hline 症例 & 下顎残存歯数 & 下顎義歯 & 対合関係（上顎） & Panorama & 下顎骨欠損* & 山本の咬度表 \\
\hline 1. & 5 本 & $(-)$ & 部分義歯 & & $\mathrm{L}$ & 3 \\
\hline 2. & 5 本 & 部分義歯 & 残存歯 & & $\mathrm{LC}$ & 6 \\
\hline 3. & Implant & 部分義歯 & 総義歯 & & $\mathrm{LC}$ & 4 \\
\hline 4. & なし & $(-)$ & 総義歯 & & LC & 3 \\
\hline 5. & 12 本 & $(-)$ & 残存歯 & & $\mathrm{L}$ & 3 \\
\hline 6. & 4 本 & 部分義歯 & 総義歯 & & $\mathrm{L}$ & 6 \\
\hline 7. & 5 本 & $(-)$ & 部分義歯 & & $\mathrm{LC}$ & 6 \\
\hline
\end{tabular}

* Boyd らの HCL 分類 ${ }^{3)}$

床面に平行になるように頭部を固定し, 感圧シート（R夕 イプ）を 3 秒以上最大咬合力にて咬ませ，専用分析装置 OCCLUZER709（GC Corporation, 東京）内のスキャナー で画像を取り込み, プレスケールの発色程度から，咬合接 触面積ならびに咬合力を計測した。

6. 術後の審美的・機能的満足度のアンケート調査 術後の顔貌に対する満足度，ならびに口胫機能に関する 満足度に関するアンケートを術後 6 ケ月以上経過した後に 実施した。アンケートを集計し，各割合を算出し評価し た。

\section{結 果}

下顎骨の欠損範囲はBoyd $5^{3)}$ の HCL 分類で, L 型 (condylar head を含まない) 3 例, 正中部も含む LC 型が 4 例であった。術後の下顎の残存歯数は 0 本〜 12 本と症 例間にばらつきがあった。また術後に義歯を使用できた症 例は 3 例であった。術後に無歯顎になるため術中に残存骨 ヘインプラントを 2 本埋入し, 術後にインプラント義歯の 作製を 1 例で施行した（症例 3 )。対合となる上係もさま ざまで, 残存歯が多数残っているものもあれば, 部分義歯 もしくは総義歯の症例もあった（表 3 )。 
表 4 Helkimo index の結果

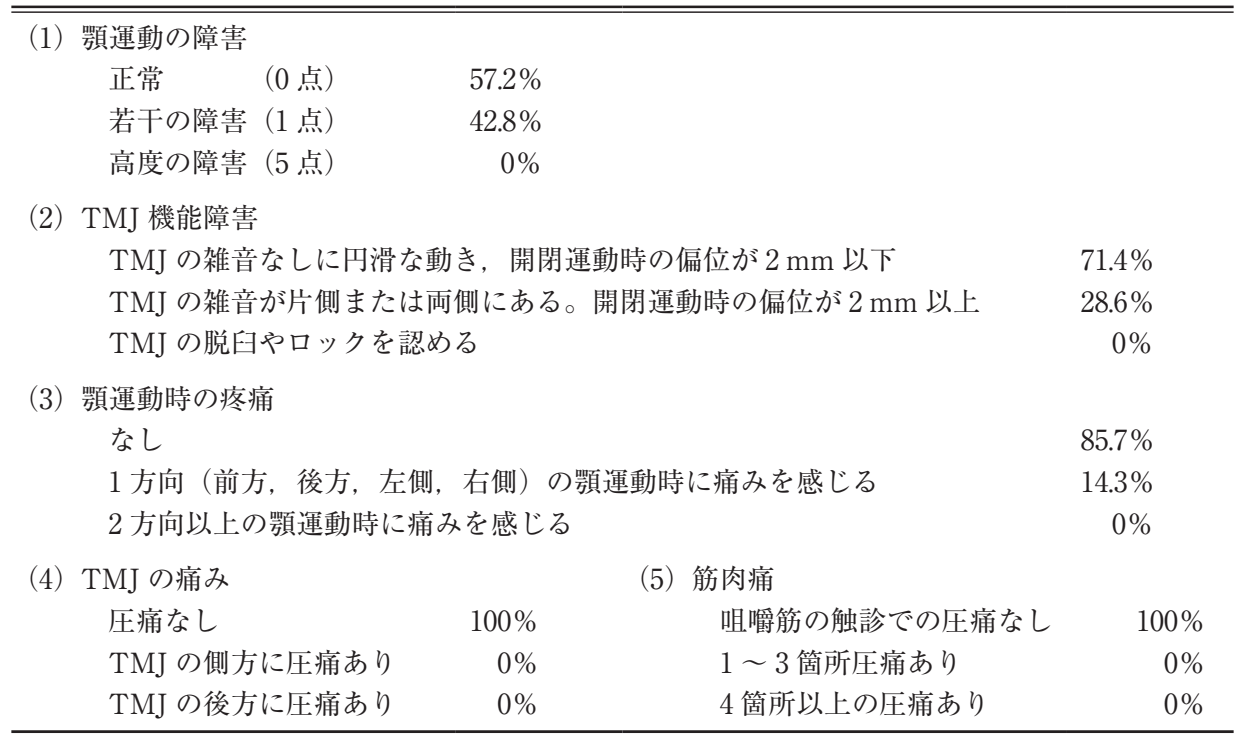

腫瘍再発が症例 1,5 の 2 例に認められた。症例 5 に関 しては術後 4 ケ月に腫瘍再発部よりプレートの露出を認め た。放射線治療として 70Gy の外照射を行ったが，制御で きず術後約 1 年に不慮の転帰となった。

今回の対象患者の転帰としては 1 例 が原発死, 1 例が 担癌生存の状態であった（表 2)。

1. 術後の合併症

周術期における合併症は認めなかったが，術後の合併症 としては局所感染 1 例，プレート破折 1 例を認めた。開口 障害，瘦孔形成，皮弁壊死を生じた症例はなかった。局所 感染症例はオトガイ部の発赤, 疼痛を認めるも抗菌薬の使 用により，症状改善した（症例 3）。プレート破折症例は 術後 30 ケ月に下顎角部に亀裂が認められ，徐々に咬合の 偏位が大きくなったため, 全身麻酔下にプレート除去を施 行し硬性再建は行わなかった（症例 2)。

\section{2. 会話機能評価}

術後の会話機能評価としては全症例ともに広瀬の分類に おける「日常会話可能, 新たな話題でも会話が可能」の 8 点以上であった。

3. 臨床的顎関節機能検査

術後にほとんどの症例において䯪運動や顎関節に臨床症 状の出現は確認されなかったため（表 4), Helkimo index を使用した 5 項目の障害度点数を加算した值の平均值は 0.86 点と低いものであった。

4. 食物摂取調査

術後 6 ケ月の時点で食物摂取評価を山本の咬度表を用い て行ったところ, 全症例の平均は 4.43 点 $(3 \sim 6$ 点) であっ た（表 3)。

5. 術後の咀嚼機能 (咬合力, 咬合接触面積)

術後無歯顎となった症例 3 (女性) に対して, デンタル プレスケールによる咀嚼機能評価を行った。下顎は術後 に左側のみのインプラント義歯を作製した。咬合力は 39.8
$\mathrm{N}$, 咬合接触面積は $0.9 \mathrm{~mm}^{2}$ であった。一方, 術後にも残 存歯が 5 本あり，上顎にも天然歯が残存した症例 7 (女性) においては咬合力が $129.4 \mathrm{~N}$, 咬合接触面積が $2.1 \mathrm{~mm}^{2}$ と高 い值を示した。

6. アンケート調査

術後の顔貌に対する満足度について, 男性は「満足して いる」あるいは「他人の視線が気にならない」と答えたの に対して，女性は「不満に思っている」あるいは「他人の 視線が気になる」との回答が多く, 顔貌に関して満足度が 十分ではなく審美的要求が高い傾向にあった。会話に関し ては全症例ともに支障ないという結果であった（表 5)。

しかし術後の食事に関するアンケート結果では「満足に 食事ができない」と答えた症例が 2 例，「工夫しないと食 事ができない」と答えた症例が 3 例と満足度が低い結果で あった。

さらに「移植骨を用いるような下顎再建手術を希望する か？」という質問に対しては 1 例のみ希望すると回答した が, 残りの患者は追加手術を希望しないとの結果であっ た。

\section{考察}

下顎骨区域切除後に咀嚼機能や審美性を回復することは 重要である ${ }^{4,5)}$ 。近年，腓骨，腸骨，肩甲骨といった血管 柄付き遊離骨皮弁が下顎骨再建に応用され，その生着率に 関しても高い成績を残している ${ }^{6)}$ 。

しかし悪性腫瘍においては，皮弁や移植骨を利用して即 時再建を行った場合，腫瘍の再発，転移を肉眼的，画像的 に評価が困難な場合がある。よって術後の経過観察に重点 を置くといった点で一時的な再建プレートによる硬性再建 は有用であると考えられる。また再建プレートは使用が簡 便で手術に要する時間も短く, 使用患者の制限が少ないこ とからも高齢者への使用における長所としてあげられる。 
表 5 アンケート調査の結果

\begin{tabular}{|c|c|c|}
\hline (1) & 術後の顔貌に対して & \\
\hline & ·大変満足している。 & $0 \%$ \\
\hline & ・満足している。 & $28.6 \%$ \\
\hline & ・どちらでもない。 & $42.8 \%$ \\
\hline & •不満に思っている。 & $14.3 \%$ \\
\hline & •非常に不満に思っている。 & $14.3 \%$ \\
\hline (2) & 他人の視線が気になりますか？ & \\
\hline & ・まったく気にならない。 & $42.8 \%$ \\
\hline & ・少し気になる。 & $28.6 \%$ \\
\hline & ·非常に気になる。 & $28.6 \%$ \\
\hline (3) & 術後の食事に関して & \\
\hline & •術前と変わりなく, 食事ができる。 & $28.6 \%$ \\
\hline & •術前ほどは食べれないが, 普通に食事が出来る。 & $0 \%$ \\
\hline & •工夫しないと食事ができない。 & $42.8 \%$ \\
\hline & ・満足に食事ができない。 & $28.6 \%$ \\
\hline & ・まったく食事ができない。 & $0 \%$ \\
\hline (4) & 術後の会話に関して & \\
\hline & •術前と変わらず, 問題なく会話できる。 & $57.2 \%$ \\
\hline & •普通に会話できる。 & $42.8 \%$ \\
\hline & ・会話がしにくく，困っている。 & $0 \%$ \\
\hline & ・会話ができない。 & $0 \%$ \\
\hline (5) & 可能であれば将来, 顎の修正手術を & \\
\hline & ・希望する。 & $14.3 \%$ \\
\hline & ・どちらでもよい。 & $0 \%$ \\
\hline & ・希望しない。 & $85.7 \%$ \\
\hline
\end{tabular}

一方で，区域切除後に硬性再建は行わずに軟組織の欠損 に対して縫縮，あるいは有茎もしくは遊離筋皮弁による補 填の久を行う再建法もある。しかし特に遊離筋皮弁は皮弁 の作製，ならびに血管吻合に時間を要しまま他部位への 外科的侵襲を考えると高齢者には負担が大きく，必ずしも 適した再建法とはいえない7.8)。また硬性再建を行ってい ない場合はいずれにおいても，残存下顎骨の偏位が大き く，咬合不全が起こり術後の咀嚼効率が低下する傾向にあ る9)。咬合誘導，リハビリ等により最終的に䫈位が再現さ れる症例も経験するが, 期間を要し術直後の咀嚼効率を考 慮すると, 再建プレートであっても硬性再建を行った症例 の方が早期に咀嚼効率が回復し, 患者の QOL も高いと言 える。杤原ら ${ }^{10)}$ は下顎骨区域切除を施行した患者の術後の 咀嚼能率に有意に影響を与える因子として「術後期間」が 強いと報告している。つまり術後 1 年以上のリハビリを行 うことで咀嚼ならびに咬合力が回復するとしている。しか し，残された時間が十分とは言えない高齢者においては術 後の回復期を短縮することも優先しなくてはならない。

今回の検討に打いて, 咀嚼機能に関するアンケート調查 では满足度が低かったものの, 実際の食物摂取評価では平 均点が 4 点と予想外に高く, 術後の機能再建という意味合 いでは十分な目的を達成できていると考える。しかし主観 的な評価と客観的な評価に差があることは過去にも報告が あり ${ }^{11)}$, 今後, 咀嚼機能に関して客観的な評価を行う必要
がある。

再建プレート使用により, 術後に生じる問題点としてま ず審美面があげられる。再建プレートは下顎骨に対して厚 みがないため, 術後に顔貌の変形が生じ, 審美的に満足を 得ることが難しい。審美的観点から下顎骨の湾曲を再現し ようとプレートを張り出し固定すると, 被覆する軟組織量 によってはプレートの露出の危険性が高くなり注意を要す る。プレートの露出は患者の QOL を著しく低下させるた め, 極力回避しなくてはならない。

次に術後，下顎骨欠損部（プレート補填部）への補綴処 置が困難であることがあげられる。実際，再建プレート上 には従来の義歯の使用は不可能となる。よって残存歯が少 ない場合は術後の咀嚼能率が著しく低下する。Endo ${ }^{122}$ は 下顎骨切除患者に扔いて, 下顎残存歯数が効率的な咀嚼に 影響を与える因子であると報告している。今回，下顎骨欠 損状態の類似した女性 2 名に関して咬合接触面積ならびに 咬合力を比較してみたが, 残存歯の有無が術後の咀嚼に影 響を与えていた。よって術後に残存歯のない，もしくは少 ない症例に対しては咀嚼機能の改善のために残存骨への デンタルインプラントの使用は非常に有用であると考え る ${ }^{13)}$ 。実際, 下顎骨切除後にインプラント義歯を使用する ことで食物摂取能が向上し患者の満足度が上がることが報 告されている ${ }^{14,15)}$ 。しかしながら，現在のところインプラ ント義歯は保険適用になって扮らず，すべての症例に打い て適応とは言えない。また今回のアンケート調查からも判 明したように, 腫瘍切除後には多くの患者が追加手術を希 望されないため, インプラント埋入手術を腫瘍切除時と同 時に施行することを考虑しても良いと考える。

最後にプレートの露出や破折の危険性が常にあり, 場合 によっては再手術が必要となる点である。再建用プレート はあくまで一時的なものであり, 感染, 露出, 破折といっ た危険性を常に持ち合わせている16-18)。われわれはプレー 卜露出の危険性を減らすため, プレートの適合の際, プ レートの湾曲を減らし，やや直線的にベンドするように心 がけている。しかし露出は減るものの, 顔貌の左右差が目 立ち審美性が低下するといった欠点もある。今回の満足度 調查に打いても審美的満足度が低かった要因の一つと考え る。破折の要因としては咬合力, あるいは長期使用による 金属疲労もあるが，プレート適合の際の粗悪なベンディン グ操作により，そのリスクが上がることも考えられる。ひ とつの解決策として，われわれは術前に実態模型を作製し 技工サイドで術前シミュレーションを行いプレートの加工 を行っている。このことで手術時間の短縮，ならびに適切 な加工が可能となる ${ }^{19-21)}$ 。一般的には以上のような問題点 を考慮し, また再建プレートの耐久性も含め約 1 年後には プレートを撤去し，自家骨を用いた硬性再建を行うことが 望ましい。

高齢者における再建プレートの永続的な使用は, 術後早 期の咀嚼機能回復のため, あるいは余命や加齢による咀嚼 力の低下を考慮すると妥当性はあるように思える。しかし 
現実的にはプレートの破折や露出といった合併症を少なか らず経験する。今後, 高齢者の下顎硬性再建に再建プレー 卜を使用する適応に関して，症例を増やし検討を加える必 要がある。

\section{結＼cjkstart論}

口腔癌のため下顎骨区域切除を行った高齢者に対する硬 性再建に再建プレートの使用は，術後の審美性，あるいは 機能面においてやや問題が残るものの, 手術時間の短縮に つながり，術後合併症が少なく，さらには術後早期の咀嚼 機能回復に貢献できる有用な方法であると考える。

本論文の要旨は第 35 回日本頭頸部癌学会（2011 年 6 月，愛知） にて発表した。

\section{文献}

1）栗田賢一，石井拓男，成田幸憲他：顎関節機能障害の検診 一第 1 報 簡易検診法について一 日口外誌 37：14991505,1991

2) Yamashita Y., Otsuka T., Shigematsu M., et al: A long-term comparative study of two rigid internal fixation techniques in terms of masticatory function and neurosensory disturbance after mandibular correction by bilateral sagittal split ramus osteotomy. Int J Oral Maxillofac Surg 40:360-305, 2011

3) Boyd J.B., Gullane P.J., Rotstein L.E., et al: Classification of mandibular defects. Plast Reconstr Surg 92:1266-1275, 1993

4) Mark R.E.: Mandibular reconstruction. J Oral Maxillofac Surg $51: 466-479,1993$

5）鄭 漢忠, 戸塚靖則, 牧野修治郎他：下顎歯肉, 口底扁平上 皮癌の下顎骨切除例における術後形態および機能の検討 日 口外誌 $38: 775-782,1992$

6) Wells M.D.: Mandibular reconstruction using vascularized bone grafts. J Oral Maxillofac Surg $54: 883-888,1996$

7) Al Quattan M.M., Boyd J.B.: Complications in head and neck microsurgery. Microsurgery $14: 187-195,1993$

8) Kroll S.S., Schusterman M.A., Reece G.P.: Costs and compli- cations in mandibular reconstruction. Ann Plast Surg 29 : 341-347, 1992

9) Mark L.U., Daniel B., Hubert W., et al: Functional evaluation following microvascular oromandibular reconstruction of the oral cancer patients: A comparative study of reconstructed and nonreconstructed patients. Laryngoscope 101:935959, 1991

10）杤原義之, 山下徹郎, 上田倫弘他：口腔癌術後患者の咀嚼機 能評価一下顎骨区域切除症例について一 顎顔面補綴 34 : $1-7,2011$

11）狩野岳史, 砂川 元：舌部分切除を行った患者の術後口䏶 機能一主観的および客観的評価一 頭頸部癌 $32: 29-33$, 2006

12) Endo N.: Studies on masticatory function in patients with surgical mandibular reconstruction. Oral Surg Oral Med Oral Pathol $34:$ 309-406, 1972.

13）後藤昌昭：顎顔面インプラントの臨床応用に関する研究 日 口科誌 $51: 1-14,2002$

14）栗田 浩, 成川純之助, 上原 忍他：たとえ数本のデンタル インプラントでも患者の QOL は向上する 頭頸部癌 32 ： $16-23,2006$

15）井原功一郎, 陣内重雄, 重松正仁他：下顎骨切除後にインプ ラント義歯を使用した場合の咀嚼機能 日口科誌 $51: 374-$ 384,2002

16）野口忠秀, 土屋欣之, 伊藤弘人他：下顎骨再建プレートと軟 組織再建を用いた下顎再建例における合併症の検討 口䏶腫 瘍 $21: 45-50,2009$

17）吉村仁志, 成相義樹, 野津一樹他：リコンストラクションプ レートとスクリューのみを用いて下顎の連続性を再建した患 者の術後合併症分析 日口診誌 20:204-209, 2007

18）片倉 朗，高木 亮，椎木さやか他：下顎再建に応用した A-O プレートの破折 口科誌 $55: 42-47,2006$

19) Goto M., Katsuki T., Noguchi N., et al: Surgical simulation for reconstruction of mandibular bone defects using photocurable plastic skull models: Report of three cases. J Oral Maxillofac Surg $55: 772-780,1997$

20）山口能正，後藤昌昭，井原功一郎他：光造形法により作製 された頭蓋顔面骨模型の下顎骨モデル複製法 顎顔面補綴 $23: 15-21,2000$

21) Yamashita Y., Yamaguchi Y., Tsuji M., et al: Mandibular reconstruction using autologous iliac bone and titanium mesh reinforced by laser welding for implant placement. Int J Oral Maxillofac Implants 23 : 1143-1146, 2008 